\title{
KNOWLEDGE AND ATTITUDE OF SECOND YEAR MEDICAL, DENTAL AND NURSING STUDENTS IN THIRUVANANTHAPURAM GOVERNMENT MEDICAL COLLEGE CAMPUS TOWARDS ORGAN AND WHOLE-BODY DONATION
}

\author{
Usha Devi Keezhathil Bhargavi1, Umesan Kannanvilakom Govindapillai²
}

1Professor, Department of Anatomy, Government Medical College, Kozhikode, Kerala, India.

${ }^{2}$ Assistant Professor, Department of Anatomy, Government Medical College, Thiruvananthapuram, Kerala, India.

ABSTRACT
BACKGROUND
Students of medical as well as paramedical courses can function as a potential source of reliable information to the lay public
regarding organ and body donation. They ultimately can play a key role in motivating the public along these lines ensuring
successful implementation of organ donation related programs like the Mrithasanjevani.

\section{METHODS}

The cross-sectional study was done after obtaining clearance from institutional research and ethics committee. The second-year students of Government Medical College, Dental College and Nursing College, Thiruvananthapuram formed the study group. They were given a questionnaire regarding the awareness of organ and body donation. Qualitative and quantitative variables of the responses were then analysed.

\section{RESULTS}

Compared to the BDS and MBBS students, BSc nursing students were well informed of the various aspects of organ donation. One surprising finding observed was a reluctance by some medical students to body donation primarily owing to the disrespect shown to the body on the dissection table, which hurts the sentiments of many aspiring medical personnel.

\section{CONCLUSIONS}

A new wave of awareness has been generated in the society regarding organ and body donation, thanks to the efforts of governmental and NGO based campaigns, talks, web and media discussions, in recent times. A well aware population of the medical personnel will help to inculcate the concept in the public and motivate them.

HOW TO CITE THIS ARTICLE: Bhargavi UDK, Govindapillai UK. Knowledge and attitude of second year medical, dental and nursing students in Thiruvananthapuram government medical college campus towards organ and whole-body donation. J. Evolution Med. Dent. Sci. 2019;8(14):1153-1155, DOI: 10.14260/jemds/2019/256

\section{BACKGROUND}

About five lack people suffer from organ failure in India. More than 1.5 lakh patients wait for kidneys, 50000 for hearts and 50000 for liver transplants. Ten lakh people suffer from blindness and await donors. In a country with a population of 1.3 billion, the donor rate is abysmally low-just 0.4 per million population as against the USA where it is 25 per million. These figures expose the huge demand supply gap. This deficit in requirement availability explains the excessive delay in transplant surgeries. Lives are lost due to lack of organ donors. Such a situation serves as a breeding ground for illicit traders. Strengthening the donor pool is the only solution for these problems. The government of Kerala implemented a program named Mritasanjeevani which has made many organ donations from deceased donors possible. KNOS - Kerala Network for Organ Sharing-is the coordinating body for the deceased donor organ transplantation program.

'Financial or Other Competing Interest': None.

Submission 01-02-2019, Peer Review 22-03-2019,

Acceptance 28-03-2019, Published 08-04-2019.

Corresponding Author:

Umesan Kannanvilakom Govindapillai,

T.C. 27/532, Raj Bhavan,

Thampuranmukku-695035

Thiruvananthapuram,

Kerala, India.

E-mail: umesankg@yahoo.com

DOI: $10.14260 /$ jemds $/ 2019 / 256$
A sound knowledge of anatomy is imperative for medical practitioners. Dissection of cadavers remains the most powerful means of teaching and learning anatomy. The spurt of medical colleges has led to dearth of cadavers. This cadaver scarcity can be overcome by enlightening the public on the importance of whole-body donation.

This research hopes to explore the levels of knowledge and attitudes of budding health professionals towards organ and whole-body donation. Awareness campaigns, educational programs, talks and discussions can be designed based on the outcome of this study. Negative attitudes that might be disclosed can be examined and appropriate remedial measures be contemplated. Sensitizing the medical personnel will help to propagate the concept and motivate the public.

The government of Kerala has launched a program named Mritasanjeevani which made many organ donations from deceased donors possible. KNOS - Kerala Network for Organ Sharing-is the coordinating body for the deceased donor organ transplantation program. The success of the program indicates that the noble concept of organ donation is being accepted by public.

\section{Objectives of The Study}

To check the level of awareness and attitude of 2 nd year medical, dental and nursing students of Govt Medical College, Thiruvananthapuram Campus towards organ donation and whole-body donation using a questionnaire-based study. 


\section{METHODS}

The study was a cross sectional one with duration of one year. The work was undertaken only after obtaining clearance from institutional research and ethics committee. The second-year students of government medical college, dental college and nursing college Thiruvananthapuram formed the study group. Those unwilling to take part were excluded. 88 MBBS, 31 dental and 58 nursing students voluntarily participated in this survey. Convenience sampling method was used in the present study. A 27-item questionnaire was used to collect data. Questions were framed to assess their knowledge regarding brain death, various organs that can be donated during and after life, their attitudes regarding donation etc. (Q1) a pilot study was conducted giving the survey forms to 10 senior students who were selected at random. This was done to rule out ambiguous questions and to confirm that the questions were correctly framed. The results of the preliminary study were scrutinized and then the present work was embarked upon. The participants of the study group were first given a brief introduction about the work and then the question sheets were distributed. Qualitative and quantitative variables of the responses were then analysed.

\section{RESULTS}

All the students had a general idea about brain death, organ donation and whole-body donation. Most of the students had acquired this information through visual and print media. Medical exhibitions, conferences, programs and exposure to dissection were other modes by which they came to know of donation.

\begin{tabular}{|c|c|c|c|c|c|c|}
\hline Course & Kidney & Liver & $\begin{array}{c}\text { Bone } \\
\text { Marrow }\end{array}$ & Lung & Pancreas & Intestine \\
\hline BDS & 96.8 & 93.5 & 12.9 & 0 & 0 & 0 \\
\hline $\begin{array}{c}\text { BSc } \\
\text { Nursing }\end{array}$ & 100 & 96.6 & 29.3 & 10.3 & 13.8 & 19 \\
\hline MBBS & 94.3 & 77.3 & 14.8 & 0 & 0 & 1.1 \\
\hline \multicolumn{7}{|c|}{ Table 1. Awareness Regarding Organs Donated } \\
During life (in \%) \\
\hline
\end{tabular}

\begin{tabular}{|c|c|c|c|c|c|c|c|}
\hline Course & Cornea & Heart & Kidney & Pancreas & Liver & Lung & $\begin{array}{c}\text { Bone } \\
\text { Marrow }\end{array}$ \\
\hline BDS & 67.7 & 51.6 & 16.1 & 6.5 & 3.2 & 0 & 0 \\
\hline $\begin{array}{c}\text { BSC } \\
\text { Nursing }\end{array}$ & 81 & 62.1 & 37.9 & 27.6 & 36.2 & 19 & 22.4 \\
\hline MBBS & 78.4 & 60.2 & 28.4 & 0 & 24 & 14.8 & 8 \\
\hline \multicolumn{7}{|c|}{ Table 2. Awareness Regarding Organs Donated after } \\
Death (in \%)
\end{tabular}

\begin{tabular}{|c|c|c|}
\hline Course & Aware & Not Aware \\
\hline BDS & 32.3 & 67.7 \\
\hline BSc Nursing & 84.5 & 15.5 \\
\hline MBBS & 80.7 & 19.3 \\
\hline \multicolumn{3}{|c|}{ Table 3. Awareness Regarding } \\
KNOS \& Mritasanjeevani (\%) \\
\hline
\end{tabular}

\begin{tabular}{|c|c|c|}
\hline Course & Willing & Not Willing \\
\hline BDS & 87.1 & 12.9 \\
\hline BSc Nursing & 89.7 & 8.6 \\
\hline MBBS & 87.5 & 8 \\
\hline \multicolumn{2}{|c|}{ Table 4. Attitude Towards Organ Donation (\%) } \\
\hline
\end{tabular}

\begin{tabular}{|c|c|c|c|}
\hline Course & Family May Object & Fear & No Reason \\
\hline BDS & 50 & 50 & \\
\hline BSc Nursing & & & 100 \\
\hline MBBS & & 29 & 71 \\
\hline \multicolumn{3}{|c|}{ Table 4a. Reasons for Non-Willingness (\%) } \\
\hline
\end{tabular}

\begin{tabular}{|c|c|c|}
\hline Course & Willing & Non-Willing \\
\hline BDS & 9.8 & 90.3 \\
\hline BSc Nursing & 24.1 & 70.7 \\
\hline MBBS & 17 & 70.5 \\
\hline \multicolumn{2}{|c|}{ Table 5. Attitude Towards Whole Body Donation (\%) }
\end{tabular}

Table 5. Attitude Towards Whole Body Donation (\%)

\begin{tabular}{|c|c|c|c|c|c|}
\hline Course & $\begin{array}{c}\text { Family May } \\
\text { object }\end{array}$ & Fear & Religious & $\begin{array}{c}\text { Disrespect } \\
\text { to Body }\end{array}$ & $\begin{array}{c}\text { No } \\
\text { Reasons }\end{array}$ \\
\hline BDS & 11 & 7 & & & 82 \\
\hline BSC Nursing & 12 & 5 & 61 & & 22 \\
\hline MBBS & 8 & & 5 & 37 & 50 \\
\hline \multicolumn{7}{|c|}{ Table 5a. Reasons for Non-Willingness (\%) } \\
\hline
\end{tabular}

\section{DISCUSSION}

The participants had a sound knowledge of brain death, organ donation and whole-body donation (Tables 1,2,3) Compared to the BDS and MBBS students, the BSc. Nursing students were well informed of the various aspects of organ donation in contrast to results of another cross sectional study conducted by Majeed. ${ }^{1}$ The higher score obtained in present study may be due to the incorporation of such topics in their first year curriculum as well as a relatively early clinical exposure of this group of students Media, print and visual is the most popular mode of propagating organ donation even among medical students. Medical exhibitions, conferences and other health programs too have helped in disseminating these concepts, though to a lesser extent. In all the categories, majority were willing to donate organs. (Table 4) As regards to whole body donation, greater part of students was averse to the idea. (Table 5) The reasons of nonwillingness for organ and body donation were many. Most of the students did not give any specific reasons for their stand. It could possibly be that they were undecided still on such matters. Some of the students were apprehensive of objection from their families. EMEKA et al, B Z De Gama ${ }^{2,3}$ A few students cited fear and disinterest as explanation for the apathetic attitude. The fore most grounds for refusal stated by the participants to donating own body for study purposes comes as a shocking realization. It is disrespect shown to the cadaver by fellow students that changed their outlook towards whole body donation. Our work corroborates with EBEYE et al. ${ }^{4}$ which reported negative attitude towards organ and corpse donation. The other reasons for refusal are personal fear and religion. (Table 4a, 5a). The main reason for unwillingness to self-donate was religious beliefs in the study conducted in undergraduate South African Students by De Gama et $\mathrm{al}^{3}$ Such observations have been recorded in other studies too. ${ }^{5}$

In a society like ours where each member of a family is consulted on all issues in the household where even personal issues are not personal but general, sensitive topics like organ and body donation are subject to enormous deliberations. Opposition to donation which may arise from any of these quarters is a cause of concern for a person who is otherwise willing. Promoting general awareness on organ and body donation through various means will enlighten the 
society about this noble gesture. Fear and lack of interest too stem from ignorance which can be removed by appropriate educative measures. Access to relevant information may stimulate the unresolved minds to think in favour of donation.6 Medical curriculum should highlight the importance of organ donation. Improving the attitudes of health care professionals could help to promote organ donation.7,8 A previously unwilling mind may alter his or her opinion when the concept is instilled into them as part of their studies, over the years. ${ }^{9}$ Discussions with religious scholars may help in allaying fears and anxiety in devout potential donors.

Dissection hall is the place where maximum learning occurs. Dissection of cadavers is the best teaching learning method in anatomy, till date .Springing up of new medical schools has led to the scarcity of bodies for study .It is in this context that the concept of whole-body donation acquires significance. Voluntary donations are required to meet this demand. Disrespecting the body on the dissection table hurts the sentiments of many aspiring medical personnel. As a potential donor population, students are reluctant to become emotionally involved in the donation process and are unwilling to become donors themselves. When those in the medical profession, especially budding doctors, who are to disseminate information on merits of donation are themselves reluctant, perspective of the general public remains to be seen. Rokade et al, Prachi et al have reported similar trends. ${ }^{9,10}$ Attitudes of medical students are to a great extent influenced by their exposure to dissection. They are reluctant to become involved in body donation process. ${ }^{11}$ In the study by Cahill $\mathrm{KC}$ et al the rapport established among medical students for donating their bodies for dissection decreased significantly after exposure to dissection (31.5\% initially . and $19.6 \%$ after dissecting for 9 weeks).This decline in affinity levels was not observed in the general population in other studies. Students prefer to learn anatomy by dissecting donors who are unknown to them. ${ }^{12}$ when the motivators of the future are not motivated on this topic, the finest technique of anatomy teaching may sink into oblivion. Well directed measures have to be executed in the preliminary orientation classes before the students are exposed to the cadavers. Students of anatomy ought to inculcate the habit of handling the body with utmost respect and dignity. They must learn to honour the dead who teach the living. Teachers must ensure that students follow the ethics and good practices in human cadaveric dissection. ${ }^{13}$

\section{CONCLUSIONS}

A new wave of awareness has been generated in the society regarding organ and body donation, thanks to the efforts of governmental and NGO based campaigns, talks, web and media discussions, in recent times. A well aware population of the medical personnel will help to inculcate the concept in the public and motivate them. Negative attitudes expressed during the disclosure should be examined by the authorities in utmost seriousness and appropriate remedial measures be undertaken after sufficient discussion with the people concerned.

\section{REFERENCES}

[1] Majeed F. Saudi nursing and medical student's knowledge and attitude towards organ donation - a comparative cross sectional study. Int Journal Health Sci (Qassim) 2016;10(2):209-17.

[2] Anyanwu EG, Obikili EN, Agu AN. The dissection room experience: A factor in the choice of organ and whole body donation - a Nigerian survey. Anatomical Sciences Education 2014;7(1):56-63.

[3] De Gama BZ, Bhengu TT, Satyapal KS. Attitudes of undergraduate South African students towards body donation. Int J Morphol 2018;36(1):130-4.

[4] Abimbola OE, Chukwuedu 0, Alabi A. Perception of organ \& corpse donation among students of basic medical sciences. Int $\mathrm{J}$ of Forensic Med Invest 2016;2(1):9-12.

[5] Mwachaka PM, Mandela P, Saidi H. Repeated exposure to dissection does not influence students' attitudes towards human body donation for anatomy teaching. Article ID 9251049, Anatomy Research International 2016;2016: p. 5.

[6] Terbonssen T, Settmacher U, Wurst C, et al. Attitude towards organ donation in German medical students. Langenbecks Arch Surg 2016;401(8):1231-9.

[7] Mekahli D, Liutkus A, Fargue S, et al. Survey of first year medical students to assess their knowledge and attitude towards organ transplantation and donation. Transplant Proc 2009;41(2):634-8.

[8] Hamed H, Awad ME, Youssef KN, et al. Knowledge and attitudes about organ donation among medical students in Egypt: a questionnaire. Journal of Transplantation Technologies \& Research 2016;6(1):155.

[9] Figueroa CA, Mesfum ET, Acton NT, et al. Medical students' knowledge and attitude towards organ donation: results of a Dutch survey. Transplant Proc 2013;45(6):2093-7.

[10] Rokade SA, Gaikawad AP. Body donation in India: social awareness willingness \& associated factors. Anat Sci Educ 2012;5(2):83-9.

[11] Aneja PS, Bansal S, Sood KS, et al. Body donation - a dilemma among doctors. JEMDS 2013;2(16):2585-93.

[12] Cahill KC, Ettarh RR. Students attitude to whole body donation are influenced by dissection. Anat Sci Educ 2008;1(5):212-6.

[13] Ghosh SK. Paying respect to human cadavers: we owe this to the first teacher of anatomy. Ann Anat 2017;211:129-34. 